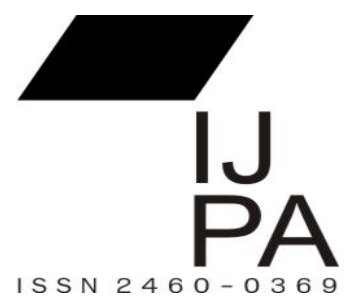

\section{PEMANFAATAN GADGET DALAM MEMAKSIMALKAN PELAYANAN MASYARAKAT}

\author{
Nur Afni Khafsoh, Imam Yudhianto Soetopo, Mahfudz Daroini \\ Dosen STISIP Muhammadiyah Madiun \\ aven.ayyubie@yahoo.com,imamyudhianto@gmail.com \\ mahfudzdaroini@gmail.com
}

\begin{abstract}
The use of gadgets in children has a positive and negative impact. The positive impact of using gadgets among others can help learn the child and can provide information about the broad knowledge and easy way to access it. While the negative impact is decreased socialization with others, addictive effects, resulting in decreased visual function and others. However, from all the shortcomings, it would be good impact the use of this gadget can make a breakthrough for the government in running the program. As is known, public service is one of the programs provided by the government in the development process, often the government program is not running properly due to the many inhibiting factors, such as access that is difficult for the public to get information, the mainset of the government that is still traditional to the public indifference in the government program. This has become a challenge for the government to create a breakthrough in government policy. As with using gadgets in the process of program socialization or program implementation. At the same time invite the community to participate actively in the development process, especially pembangunnan village potential to be developed. However, it is not easy to use technological advances in the implementation of government programs. The obstacles faced are infrastructure preparation and human resource capability. So that community participation in the development process can increase and society can be the subject in the nation's progress.
\end{abstract}

Keywords: Gadget, Community Service, Technology Utilization

Abstrak: Penggunaan gadget pada anak memiliki dampak positif dan negatif. Dampak positif dari penggunaan gadget yaitu dapat membantu belajar anak, dapat memberikan informasi tentang ilmu pengetahuan yang luas dan mudah mengaksesnya. Sedangkan dampak negatifnya yaitu menurunnya sosialisasi dengan orang lain, memberikan efek kecanduan, mengakibatkan menurunnya fungsi penglihatan dan lain-lain. Namun, dari segala kekurangan tersebut, alangkah baiknya dampak penggunaan gadget ini dapat menjadikan terobosan bagi pemerintah dalam menjalankan programnya. Seperti diketahui, pelayanan masyarakat menjadi salah satu program yang disediakan pemerintah dalam proses pembangunan, seringkali program pemerintah tidak berjalan sesuai mestinya dikarenakan banyaknya faktor penghambat, seperti akses yang sulit dimiliki masyarakat untuk mendapat informasi, mainset oknum pemerintah yang masih tradisional hingga ketidakpedulian masyarakat dalam program pemerintah. Hal ini menjadi sebuah tantangan bagi pemerintah untuk menciptakan terobosan dalam kebijakan pemerintah. Seperti dengan menggunakan gadget dalam proses sosialisasi program ataupun pelaksanaan program. Sekaligus mengajak masyarakat untuk berpartisipasi aktif dalam proses pembangunan, terutama pembangunnan desa yang potensial untuk dikembangkan. Namun, tidak mudah menggunakan kemajuan teknologi dalam pelaksanaan program pemerintah. Kendala yang dihadapi adalah persiapan infrastruktur dan kemampuan sumber daya manusia. Tentunya hal ini dapat meningkatkan partisipasi masyarakat dalam pembangunan.

Kata kunci: Gadget, Pelayanan Masyarakat, Pemanfaatan Teknologi 


\section{Pendahuluan}

Anak adalah generasi penerus yang akan membawa tampuk kepemimpinan di masa depan. Masa depan anak dipengaruhi oleh cara mendidik dan lingkungan sosial dimana mereka tinggal. Kebutuhan akan pentingnya pendidikan bukan hanya tugas guru di bangku sekolah, namun juga merupakan tugas orang tua yang mendampingi anak dan mengantarkan pada pintu gerbang masa depan. Selain itu, tugas untuk mempersiapkan generasi yang baik juga merupakan tugas Pemerintah. Pemerintah bertugas merancang dan melaksanakan regulasi untuk mempersiapkan lingkungan yang kondusif dan mampu meningkatkan kemampuan dan kreatifitas anak.

Kota Madiun merupakan salah satu kabupaten yang berkomitmen untuk mewujudkan Kota Layak Anak (kominfo, 2017). Komitmen ini diawali dengan pertemuan Pemerintah Kota Madiun melalui Dinas Sosial, Pemberdayaan Perempuan, dan Perlindungan Anak Kota Madiun yang membahas capaian indikator dalam program ini. Dari 28 Kabupaten/Kota baru 14 Kabupaten/Kota yang mengupayakan terlaksananya program ini.

Penerapan program ini tentunya juga harus memahami permasalahan yang mendasar yang dialami oleh anak anak. Berbicara soal anak, tentunya tidak terlepas dari perubahan globalisasi yang begitu cepat. Hal ini diperjelas dengan kemajuan yang tekhnologi yang pesat yang menuntut setiap orang terutama anak anak untuk segera beradaptasi dengan perkembangan tekhnologi.

Perkembangan teknologi sangat pesat dan memiliki dampak yang luar biasa pada kehidupan manusia. Segala hal terasa menjadi semakin mudah dengan adanya teknologi. Hal yang paling nampak adalah penggunaan smartphone. Dimana setiap orang hari ini memanfaatkan smartphone sebagai kebutuhan. Penggunaan smartphone pun tidak terbatas pada usia maupun stratifikasi sosial. Segala kalangan sekarang menggunakan smartphone untuk memenuhi kebutuhan.

Keberadaan Tekhnologi yang semakin canggih memang memberikan manfaat yang luar biasa kepada masyarakat terutama Gadget. Kata Gadget sendiri berasal Inggris yang jika dibahasa Indonesiakan menjadi Gawai. Gawai dalam Kamus Besar Bahasa Indonesia berarti Perkakas (KBBI, 2016). Gawai atau Gadget merupakan sebuah instrument atau peranti yang dirancang secara spesifik lebih canggih dibandingkan dengan teknologi dan memiliki unsur kebaruan dan berukuran lebih kecil (Wikipedia, 2016).

Dengan adanya Gadget atau Gawai ini memiliki banyak sekali manfaat. Manfaat yang dapat diperoleh dari penggunaan Gadget antara lain, mempermudah manusia untuk mendapatkan pengetahuan yang luas. Globalisasi yang terus berkembang sejalan dengan pesatnya perkembangan tekhnologi. Kini, orang dari 
berabagai belahan dunia bisa saling memberi dan menerima informasi. Berbagai fitur dan kecanggihan tekhnologi dapat dirasakan dari sebuah benda kecil bernama smartphone. Smartphone atau dalam bahasa Indonesia disebut dengan telepon pintar mampu memberikan banyak manfaat. Seperti halnya pertukaran informasi yang cepat dan murah diseluruh belahan dunia. Selain itu, kini telepon pintar dapat digunakan dalam memenuhi kebutuhan manusia. Transaksi yang mudah dapat dilakukan dengan hanya menggunakan telepon pintar seperti halnya transaksi ekonomi dan transaksi informasi.

Beragam aplikasi yang disuguhkan oleh smartphone pun memiliki unsur entertainment atau hiburan bagi banyak orang. Mulai dengan aplikasi permainan sampai pada aplikasi yang berisi ilmu pengetahuan. Beragamnya aplikasi ini yang membuat banyak orang betah untuk menggunakan aplikasi yang disajikan pada gadget.

Namun, dibalik segudang manfaat yang ada pada gadget, banyak pula hal yang dapat merugikan penggunanya. Ada pengaruh antara penggunaan gadget dengan tingkat prestasi siswa. Bahwa ditemukan adanya hubungan antara penggunaan gadget dengan tingkat prestasi belajar siswa di SMA Negeri 9 Manado dan penelitian ini menunjukkan bahwa siswa yang jarang menggunakan gadget memiliki tingkat prestasi yang tinggi (Manumpil, Ismanto, \& Onimbala, 2015).

Selain itu, penggunaan pada juga mempengaruhi sosialisasi. Ada pengaruh penggunaan gadget dengan kemampuan bersosialisasi pada remaja (Irawan \& Armayati, 2013). Hal ini dikarenakan semakin banyak penggunaan gadget akan mengurangi waktu untuk berinteraksi dengan sesama teman. Hal ini dikarenakan banyaknya aplikasi yang disajikan sehingga tidak membuat pengguna gadget cepat bosan. Berfariasinya gadget dan segala fiturnya membuat masyarakat semakin terlena dan menikmati fitur gadget yang semakin hari semakin canggih dan selalu ada inovasi. Hal ini membuat semakin menurunnya minat untuk saling menjalin hubungan nyata dengan orang lain.

Di sisi lain, penggunaan gadget sebenarnya memiliki pengaruh yang lebih luas jika dimanfaatkan dengan baik. Perkembangan tekhnologi tentu tidak hanya dapat dirasakan bagi perseorangan. Namun juga bisa dirasakan dan dimanfaatkan oleh kelompok atau lembaga sosial masyarakat.

Seperti pada kasus implementasi E-Service pada organisasi publik bidang pelayanan pendidikan yang telah diterapkan di Dinas Pendidikan Kota Malang. Hasil dari penelitian ini menunjukkan bahwa Implementasi Program Penerimaan Siswa Baru Real Time Online dari Dinas Pendidikan Kota Malang berhasil dalam menyelenggarakan pelayanan publik yang mengadopsi penggunaan tekhnologi 
informasi dan komunikasi dan mewujudkan prinsip-prinsip Good Governance terutama dalam aspek transparansi, efisiensi, dan kesederhanaan (Pratiwi, Wijaya, \& Prasetyo, 2013).

Selain itu, penerapan e-government membantu dalam meningkatkan kinerja, efektifitas dan efisiensi pekerjaan dan pelayanan. (Nasrudin, 2014). Terbukti bahwa pemanfaatan teknologi mampu memberikan pengaruh positif dan manfaat bagi masyarakat luas jika digunakan dengan baik. Sehingga pemanfaatan yang baik ini dapat meminimalisir pengaruh negative dari keberadaan teknologi informasi.

Pemanfaatna teknologi informasi yang maju ini dapat digunakan sebagai ajang untuk semakin meningkatkan kontribusi masyarakat dalam memajukan daerah, terlebih pada hal sosialisasi program, peningkatan ekonomi, pemberdayaan masyarakat hingga pada meningkatkan partisipasi masyarakat dalam program yang ingin pemerintah capai. Sehingga program yang dilaksanakan oleh pemerintah dapat terlaksana dengan baik.

Harapannya, bahwa penggunaan gadget yang telah meluas di kalangan masyarakat terutama anak anak dapat meningkatkan pengetahuan dan informasi terkait program pemerintah. Sehingga dalam pelaksanaan program Pemerintah anak anak tidak hanya bisa menjadi obyek dalam program namun juga sebagai subyek yang dapat meningkatkan keberhasilan sebuah program.

Oleh karenanya, dalam rangka meningkatkan pelayanan publik dan meningkatkan partisipasi masyarakat terhadap program Pemerintah agar tercipta kesejahteraan masyarakat melalui penggunaan inovasi e-government dan pemaksimalan gadget untuk mempermudah akses informasi program Pemerintah, perlu adanya informasi terkait pemanfaatan gadget dan kemampuan masyarakat menggunakan gadget. Sehingga dalam penelitian ini ingin melihat pemanfaatan gadget dalam peningkatan partisipasi masyarakat. Penelitian ini dilakukan di Desa Sidorejo Kecamatan Kebonsari Kabupaten Madiun. Selain itu, penelitian ini juga ingin melihat pelayanan Pemerintah Desa dalam memberikan informasi dan pelaksanaan program Pemerintah Desa kepada masyarakat.

\section{Kajian Teori}

Kajian penelitian ini menggunakan Paradigma Sosial. Paradigma Sosial menjelaskan bahwa masyarakat sebagai fakta yang berdiri sendiri. Masyarakat memiliki struktur, bentuk pengorganisasian, aturan, hirarki keuasaan, peranan, nilai dan norma yang disebut sebagai pranata sosial (Said, 2013). Penelitian ini menggunakan Pendekatan Strukturalis Fungsionalis. Malinowski dalam Marzali mengatakan bahwa kegunaan institusi memenuhi kebutuhan psiko-biologis individu sebagai bagian dari masyarakat (Marzali, 2014). Teori Strukturalis Fungsionalis 
digunakan dalam melihat kebijakan Pemerintah terkait program Madiun Kota Layak Anak.

\section{Teori Kesejahteraan Sosial}

Pembangunan Kesejahteraan sosial merupakan usaha yang terencana dan melembaga yang meliputi berbagai bentuk intervensi sosial dan pelayanan sosial untuk memenuhi kebutuhan manusia, mencegah dan mengatasi masalah sosial, serta memperkuat institusi institusi sosial (Suharto, 2007) Lebih lanjut Suharto (Suharto, 2009) menyatakan bahwasanya tujuan pembangunan kesejahteraan sosial adalah untuk meningkatkan kualitas hidup manusia secara menyeluruh yang mencakup:

a. Peningkatan standar hidup, melalui seperangkat pelayanan sosial dan jaminan sosial segenap lapisan masyarakat, terutama kelompok masyarakat yang kurang beruntung dan rentan sangat memerlukan perlindungan sosial.

b. Peningkatan keberdayaan melalui penetapan sistem dan kelembagaan ekonomi, sosial dan politik yang menjunjung harga diri dan martabat kemanusiaan.

c. Penyempurnaan kebebasan melalui aksesibilitas dan pilihan-pilihan kesempatan sesuai dengan aspirasi, kemampuan dan standar kemanusiaan.

Lebih disederhanakan lagi fungsi pembangunan dapat dirumuskan menjadi tiga tugas utama yang musti dilakukan, diantaranya adalah (i).fungsi pertumbuhan ekonomi yang konsen pada bagaimana melakukan wirausaha guna mendapatkan profit untuk pemenuhan kebutuhan masyarakat. (ii). Fungsi perawatan masyarakat yaitu merujuk pada bagaimana merawat dan melindungi warga negara dari berbagai resiko yang mengancam kehidupannya. (iii). Fungsi pengembangan manusia mengarah pada peningkatan kompetensi sumber daya manusia yang menjamin ketersediaan angkatan kerja yang berkualitas yang mendukung mesin pembangunan. Hal ini dimaksudkan agar pembangunan nasional berjalan optimal dan mampu bersaing di pasar global.

2. Tingkatan Pelaksanaan E-Government

Ada 4 tingkatan dalam pelaksanaan E-Government yang ditulis dalam Buku Panduan Penyelenggaraan Situs Pemerintah Darah, Depkominfo 2003 (Sosiawan, 2008)

a. Persiapan

Pembuatan sarana media komunikasi dan komunikasi lembaga. Sosialisasi situs di internal dan publik.

b. Pematangan

Peningkatan informasi publik yang interaktif. Keterbukaan informasi dengan pihak lain. 
c. Pemantapan

Peningkatan situs yang lebih transaksionable dalam pelayanan publik. Pembuatan interoperabilitas aplikasi dan data dengan lembaga lain.

d. Pemanfaatna

Pembuatan aplikasi yang bersifat Govermnet to Government, Government to Bussiness, Government to Customer.

\section{Metode Penelitian}

Jenis penelitian dalam penelitian ini adalah kualitatif. Penelitian ini dilakukan menggunakan pendekatan studi kasus. Studi kasus adalah dimana seorang peneliti mengeksplorasi kehidupan nyata (Creswell, 2014). Penelitian ini dilakukan secara partisipatif. Fokus dari penelitian ini adalah menganalisis penyalahgunaan gadget dan dampaknya serta pelayanan pemerintahan Desa kepada Masyarakat dan tingkat partisipasi masyarakat dalam membangun desa di Desa Sidorejo, Kecamatan Kebonsari, Kabupaten Madiun. Serta ingin melihat peluang untuk dapat diterapkannya program pemerintah desa dengan memanfaatkan teknologi khususnya gadget.

\section{Hasil Dan Pembahasan}

\section{Penggunaan Gadget Pada Anak di Desa Sidorejo, Kebonsari, Kabupaten Madiun}

Dari hasil identifikasi lapangan ditemukan bahwa kebanyakan responden tidak memperbolehkan atau tidak setuju kalau anak memiliki gadget atau Gawai, karena belum waktunya mengoperasikan smartphone atau telepon pintar secara mandiri dan bebas. Akan tetapi beberapa orang tua memperbolehkan anaknya untuk menggunakan gadget sebagai reward atau hadiah. Selain itu, kurangnya kontrol orang tua karena orang tua tidak tinggal di rumah, melainkan kerja di luar kota dan luar negeri. Sedangkan yang mengontrol adalah kerabat keluarga lain yang tidak mengetahui tentang fungsi dan pemanfaatan gadget. Meskipun kerabat juga sudah memberikan jadwal untuk anak agar tidak terlalu sering menggunakan gadget.

Kebanyakan anak menggunakan gadget untuk bermain game, mengakses youtube, dan sosial media. Selain itu untuk berkomunikasi dengan orang tua yang tidak tinggal dengan anaknya. Namun, ada beberapa anak yang menggunakan game untuk belajar, seperti game edukasi. Namun, ada juga anak mengunakan smartphone untuk referensi tugas dan pelajarannya di sekolah dan bermain game untuk hiburan. Tapi kebanyakan menggunakan smartphone untuk berkomunikasi dengan orang tua dan teman. Selain itu, beberapa orang menanggapi bahwa smartphone tidak bermanfaat bagi anak, hanya menjadikan anak menjadi malas, dan mengganggu 
waktu belajar. Ada juga responden berpendapat bahwa penggunaan smartphone dapat menambah wawasan anak terutama dalam membantu mengerjakan tugas sekolah.

Perkembangan media teknologi informasi dan komunikasi pada era sekarang ini menunjukkan betapa semakin banyaknya media komunikasi yang beredar dalam masyarakat. Sebagai bentuk arus globalisasi begitu cepat merasuk ke dalam masyarakat terutama di kalangan anak-anak usia Sekolah Dasar dan pengaruhnya begitu kuat. Salah satunya adalah membuat anak-anak kehilangan kepribadian diri dan ketergantungan dengan penggunaan smartphone.

Indonesia merupakan salah satu negara berkembang didunia yang telah memulai babakan baru dalam tata cara pengaturan beberapa sistem komunikasi melalui media internet yakni seperti informasi, pertukaran data, transaksi online tertera dalam UU Nomor 36 Tahun 1999 pasal 4 tentang Pembinaan Telekomunikasi yang berisi :

1. Telekomunikasi dikuasai oleh Negara dan pembinaannya dilakukan oleh Pemerintah.

2. Pembinaan telekomunikasi diarahkan untuk meningkatkan penyelenggaraan telekomunikasi yang meliputi penetapan kebijakan, pengaturan, pengawasan dan pengendalian.

3. Dalam penetapan kebijakan, pengaturan, pengawasan dan pengendalian di bidang telekomunikasi, sebagaimana dimaksud pada ayat (2), dilakukan secara menyeluruh dan terpadu dengan memperhatikan pemikiran dan pandangan yang berkembang dalam masyarakat serta perkembangan global. Serta UU Nomor 36 Tahun 1999 pasal 2 yang berisi Asas dan Tujuan Telekomunikasi : Telekomunikasi diselenggarakan berdasarkan asas manfaat, adil dan merata, kepastian hukum, keamanan, kemitraan, etika, dan kepercayaan pada diri sendiri.

Dengan ini maka pemerintah Indonesia mengawal pengaturan terhadap telekomunikasi di seluruh Indonesia, untuk melindungi negara dan para pengguna telekomunikasi harus menggunakan sesuai etika dan menjamin tidak mengancam keamanan bagi diri sendiri dan masyarakat.

Namun, Perkembangan teknologi tidak akan terlepas dari berbagai dampak negatif yang sekarang amat kita rasakan, salah satunya mudahnya situs dewasa yang diakses oleh siapa saja. Mempertimbangkan hal tersebut maka Pemerintah berupaya melindungi warga negaranya perlu diintensifkan demi penyelamatan generasi ke depan. Upaya pemerintah menanggulangi kejahatan cyberporn dalam lingkup nasional, pemerintah dengan mengeluarkan Undang-undang Nomor 11 Tahun 2008 Tentang Informasi Dan Transaksi Elektronik, karena kejahatan cyberporn sebenarnya merupakan suatu perbuatan melanggar hukum yang secara khusus telah diatur dalam Undang-Undang tersebut. akan tetapi UU Nomor 36 Tahun 1999 pasal 4 tentang 
Pembinaan Telekomunikasi dan Undang-undang Nomor 11 Tahun 2008 Tentang Informasi Dan Transaksi Elektronik cyberporn saja di pandang belum cukup tanpa didukung peran Orangtua, peran Sekolah dan peran lingkungan masyarakat.

Menurut Abu Ahmadi dalam Hendi Suhendi dan Ramdani Wahtu (Ahmadi, 2007) penjelasan tentang orangtua dalam pendidikan sebagai berikut, Setelah sebuah keluarga terbentuk, anggota keluarga yang ada didalamnya memiliki tugas masingmasing. Teori didukung diperkuat oleh pendapat Edy bahwa peran orangtua dalam penggunaan gadget anak yang meliputi pemberian gadget pada anak sesuai keperluannya, melibatkan anak dalam berfikir, pemberian batas waktu dalam penggunaan internet, melakukan teknik-teknik penyesuaian, mengajak anak dengan berdialog tanpa menghakimi (edy, 2015). Disisi lain menurut Nurudin bahwa teknologi membentuk individu bagaimana cara berpikir, berperilaku dalam masyarakat, dan teknologi tersebut akhirnya mengarahkan manusia untuk berfikir inovatif dan kreatif (Nurudin, 2009).

Sehingga, peranan orangtua dalam memberikan gadget pada anak sesuai keperluannya secara garis besar jika anak membutuhkan Telepon selular untuk berkomunikasi, maka cukup berikan mereka ponsel sederhana untuk menelpon dan mengirim pesan. Orangtua yang memberikan gadget pada anak mereka harus mempunyai tujuan yaitu mendidik anak mereka sesuai dengan zamannya, seperti diketahui banyak kemudahan yang didapatkan dari gadget, orangtua memberikannya dengan alasan yaitu mempermudah komunikasi serta menjadi sarana informasi dan pengetahuan yang bisa diakses dengan mudah menggunakan internet, kemudian juga mempermudah anak untuk memperoleh informasi tentang pelajaran serta dampak positif pada segi sosial anak antar teman mereka.

Orangtua juga bisa menjadikan gadget sebagai motivasi atau reward anak, apabila anak mempunyai prestasi dalam bidang akademik maupun seni di sekolah. Orangtua juga harus mengajarkan anak menggunakan barang sesuai fungsinya, karena tujuan utama pemberian gadget pada anak untuk memperoleh informasi tentang pelajaran, kemudian mempermudah dalam sosialisasi antar teman. Selain itu gadget tidak hanya digunakan untuk hiburan saja tetapi gadget juga memberikan kemudahan untuk mengakses berbagai informasi dan pengetahuan melalui internet. Namun, bermain gadget dapat menimbulkan efek candu atau ketagihan pada anak. Menurut Edy bahwa Orangtua melakukan peranan mereka dengan cara memberikan batas waktu dalam penggunaan internet yaitu memberikan penjelasan terlebih dahulu tentang aturan penggunaan internet yang dibatasi, jadi tidak hanya sekedar melarang tetapi anak juga tau apa alasan mengapa dibuat aturan seperti itu, kemudian setelah diberi penjelasan maka antara orangtua dan anak membuat perjanjian mengenai penggunaan gadget secara berbatas lalu orangtua bekerjasama dalam memberikan peraturan pada anak, selalu memonitor penggunaan akses internet anak kemudian 
penerapan batasan atau lama waktu penggunaan dan pengumpulan dan tentunya atas pantauan dari orangtua (edy, 2015).

Edy juga menjelaskan agar selalu berdiskusi dan bernegosiasi dengan anak mengenai apa saja peraturan berinternet dalam keluarga. Setiap keluarga mempunyai peraturan yang berbeda-beda (edy, 2015). Dengan negosiasi peraturan yang dibuat adalah kesepakatan bersama bukan hanya perintah yang searah dari orangtua. Orangtua sebaiknya memberikan batas waktu penggunaan handphone kepada anak, tujuannya tentu saja agar tidak memberikan efek candu kedepannya, kemudian juga peraturan ini dibuat agar anak lebih berkonsentrasi terhadap pembelajaran.

Gadget memang memiliki dampak positif bagi pola pikir anak yaitu membantu anak dalam mengatur kecepatan bermainnya, mengolah strategi dalam permainan dan membantu meningkatkan kemampuan otak kanan anak. Tetapi dibalik kelebihan tersebut juga dapat berdampak buruk pula bagi daya kembang anak. Berbagai radiasi didalam gadget yang dapat merusak jaringan syaraf dan otak anak bila anak sering menggunakan gadget. Selain itu, juga dapat menurunkan daya aktif anak dan kemampuan anak untuk berinteraksi dengan orang lain. Anak menjadi kurang interaktif dan lebih suka sendiri dengan zona nyamannya bersama gadget. Sehingga menimbulkan sikap individualis pada anak dan kurangnya sikap peduli terhadap sesama baik terhadap teman, maupun orang lain. Pada akhirnya mereka terjebak dengan dunianya sendiri dan secara parktis menjadikan mereka pribadi yang sudah jelas gagah dalam berteknologi tapi gagap dalam berinteraksi.

\section{Pelayanan Publik Pemerintah Desa Sidorejo, Kebonsari, Kabupaten Malang}

Dari hasil identifikasi lapangan ditemukan pada umumnya masyarakat di desa Sidorejo mengenal perangkat desanya. Dari sejumlah warga yang dimintai keterangan tentang politik dan pemerintahan terutama dalam pengelolaan pemerintahan desa hanya satu responden yang kurang mengenali perangkat desa, karena lama menjadi Tenaga Kerja Wanita (TKW). Masyarakat rata-rata mampu menyebutkan nama nama perangkat desa seperti : kepala dusun, kepala urusan pembagunan, kaur kesejahteraan, bendahara desa, sekretaris desa (carik) dan kepala desa.

Pelayanan masyarakat yang dilakukan oleh perangkat desa menurut warga selama ini cukup baik, hal yang nampak dirasakan oleh masyarakat dalam pelayanan surat menyurat sudah dapat dilakukan dengan cepat, transparan, proses sesuai dengan prosedur, dan gratis. Akan tetapi masih ditemukan adanya oknum perangkat desa yang belum dapat mengkomunikasikan informasi pelayanan publik secara baik.

Penilaian masyarakat terhadap peningkatan pemberdayaan lingkungan seperti pembangunan infrastruktur (kegiatan fisik), pengaspalan jalan, pembangunan irigasi, pemasangan gorong-gorong di lingkungan masjid sudah cukup baik. Namun ada 
beberapa aspirasi dari masyarakat yang belum terealisasi di antaranya: pembinaan di bidang pertanian dan peternakan untuk mengatasi masalah di saat musim tanam, distribusi pupuk dan bibit. Selain itu, pembangunan di bidang peternakan, masyarakat mengharapkan untuk difasilitasi dalam bentuk pelatihan strategi budidaya peternakan, pemberian vaksin dan cara pembuatan pakan yang efektif dan berkualitas. Selain itu, masyarakat membutuhkan pelebaran jalan menuju area persawahan karena saat musim panen kendaraan roda empat tidak bisa melewati jalan tersebut.

Selain aspirasi di atas, ada salah satu dari warga yang sejak tahun 2014 lalu telah mendirikan perpustakaan "asri". Perpustakaan tersebut sengaja didirikan atas inisiatif pribadi, yang ingin memajukan dunia pendidikan, dan menambah minat baca masyarakat terutama pelajar. Salah seorang yang awalnya adalah seorang perantau yang pindah-pindah lokasi. Kini dia bekerja serabutan, sebagai kuli bangunan, tukang las hingga tukang cari rumput. Saat ini, perpustakaan tersebut terdiri dari lebih 1,000 eksemplar, dan itu murni dari dana pribadi, tanpa campur tangan pihak desa.

\section{Analisis}

Secara historis desa merupakan cikal bakal terbentuknya masyarakat politik dan pemerintahan di Indonesia jauh sebelum negara bangsa ini terbentuk, struktur sejenis desa, masyarakat adat dan sebagainya telah menjadi institusi sosial yang mempunyai posisi yang sangat penting. Desa merupakan institusi yang otonom dengan tradisi, adat istiadat dan hukumnya sendiri serta relatif mandiri. Ketika diberlakukannya Undang Undang Nomor 6 Tahun 2014 Tentang Desa di Indonesia, berbagai pihak telah banyak memberikan apresiasi kepada pemerintah pusat terhadap perkembangan otonomi desa yang sebelumnya kebijakan pengaturan tentang desa mengalami pasang surut, sekaligus dengan UU Desa ini nantinya desa -desa di Indonesia mempunyai masa depan yang lebih baik pengaturannya daripada UU sebelumnya yaitu UU Nomor 5 Tahun 1979 tentang Desa, UU Nomor 22 Tahun 1999 Tentang Pemerintahan Daerah dan UU Nomor 32 Tahun 2004 tentang Pemerintahan Daerah termasuk didalamnya mengatur tentang desa-desa di Indonesia (S, 2016).

Disisi lain dalam pemberlakuan UU Desa yang baru ini yaitu UU Nomor 6 Tahun 2014 Tentang Desa, tanggapan, dan harapan dari berbagai pihakpun bermunculan berharap aparatur desa dapat maksimal dalam mengimplementasikan kebijakan pusat dan daerah dalam konteks pelaksanaan program-program pemberdayaan masyarakat, transparansi dan akuntabilitas pengelolaan Anggaran, dan utamanya harapan akan meingkatnya kualitas mutu Pelayanan Publik.

Apabila dicermati secara seksama, Undang Undang Desa secara implisit telah mengamanatkan arah kebijakan desa, diantaranya : pertama, meningkatkan kualitas dan kuantitas pelayanan publik dan kesejahteraan masyarakat; kedua, menciptakan efisiensi dan efektivitas pengelolaan sumberdaya lokal/daerah untuk kepentingan 
peningkatan kesejahteraan masyarakat; dan ketiga, untuk memberdayakan dan menciptakan ruang bagi masyarakat untuk berpartisipasi dalam proses pemerintahan dan pembangunan (B, 2013).

Sebagaimana diketahui, Desa merupakan unit pemerintah terendah yang diakui dalam sistem penyelenggaraan pemerintahan nasional dalam bingkai Negara Kesatuan Republik Indonesia. Ini dapat diartikan bahwa Pemerintah Desa merupakan organisasi pemerintah terdepan di dalam penyelenggaraan pelayanan publik.Oleh karena itu, Pemerintah Desa dituntut untuk dapat meningkatkan kinerjanya di dalam penyelenggaraan pelayanan publik sesuai dengan harapan masyarakat.

Harus diakui bahwa pelayanan publik yang dilaksanakan oleh pemerintah terus mengalami pembaharuan, baik dari sisi paradigma maupun format pelayanan seiring dengan meningkatnya tuntutan masyarakat dan perubahan di dalam pemerintah itu sendiri. Meskipun demikian, pembaharuan dari kedua sisi tersebut belumlah memuaskan, bahkan masyarakat masih sering diposisikan sebagai pihak yang tidak berdaya dan termaginalisasikan dalam kerangka pelayanan (Sinambela \& dkk, 2010).

Undang-Undang Nomor 25 Tahun 2009 Tentang Pelayanan Publik juga menyatakan bahwa dewasa ini penyelenggaraan pelayanan publik masih diperhadapkan pada kondisi yang belum sesuai dengan kebutuhan dan perubahan di berbagai bidang kehidupan bermasyarakat, berbangsa dan bernegara.Hal tersebut bisa disebabkan oleh ketidaksiapan untuk menanggapi terjadinya transformasi nilai yang berdimensi luas serta dampak berbagai masalah pembangunan yang kompleks (Dwiyanto \& dkk, 2010)

Sementara itu tatanan baru masyarakat diperhadapkan pada harapan dan tantangan global yang dipicu oleh kemajuan di bidang ilmu pengetahuan, informasi, komunikasi, transportasi, investasi dan perdagangan.Kondisi seperti ini perlu disikapi secara bijak melalui langkah-langkah kegiatan yang terus menerus dan berkesinambungan dalam berbagai aspek pembangunan. Untuk itu diperlukan konsepsi tentang pelayanan publik yang berisi nilai, persepsi, dan acuan perilaku yang mampu mewujudkan hak asasi manusia sebagaimana yang diamanatkan oleh UUD 1945 dapat diterapkan sehingga masyarakat memperoleh pelayanan sesuai dengan harapan dan cita-cita tujuan nasional sesuai dengan UU No.25 Tahun 2009.

Kehadiran Undang-Undang Pelayanan Publik Nomor 25 Tahun 2009 dimaksudkan untuk memenuhi kepastian hukum dalam hubungan antara masyarakat dan penyelenggara dalam pelayanan publik; terwujudnya batasan dan hubungan yang jelas tentang hak, tanggung jawab, kewajiban, dan kewenangan seluruh pihak yang terkait dengan penyelenggaraan pelayanan publik; terwujudnya system penyelenggaraan pelayanan publik yang layak sesuai dengan asas-asas umum pemerintahan dan korporasi yang baik; terpenuhinya penyelenggaraan pelayanan 
publik sesuai dengan peraturan perundang-undangan; dan terwujudnya perlindungan dan kepastian hukum bagi masyarakat dalam penyelenggaraan pelayanan publik. Dengan demikian dapat dikatakan bahwa kehadiran UU No.25 Tahun 2009 diharapkan akan dapat meningkatkan kinerja organisasi penyelenggara pelayanan publik, tidak terkecuali organisasi pemerintah desa sebagai institusi pemerintah terdepan atau yang paling dekat dengan masyarakat dalam penyelenggaraan pelayanan publik (Lukman, 2012).

Untuk mewujudkan kinerja optimal Pemerintah Desa dalam penyelenggaraan publik maka harus didukung dengan adanya sumberdaya manusia aparatur yang memadai baik secara kuantitas maupun kualitas, serta tersedianya sarana dan prasarana serta fasilitas pelayanan yang memadai.Namun secara umum jika kita lihat kondisi sumberdaya aparatur pemerintah desa, serta sarana/prasarana dan fasilitas pelayanan belum memenuhi harapan yang sesungguhnya.Kondisi tersebut diakui atau tidak, memberi dampak yang kurang baik pada kinerja aparatur Pemerintah Desa dalam penyelenggaraan pelayanan publik (Kurniawan, 2015).

Dari pengamatan secara umum di lapangan, menunjukkan bahwa kinerja Pemerintah Desa dalam pelayanan publik secara umum masih banyak kelemahan baik pada aspek efektivitas pelayanan, efisiensi pelayanan, responsivitas pelayanan, dan kualitas layanan. Kelemahan pada aspek efektivitas dapat dindikasikan oleh ketidakmampuan pemerintah desa dalam mengembangkan dan melaksanakan program pelayanan kepada masyarakat yang menjadi ruang lingkup tugas pemerintah desa.Kelemahan kinerja pada aspek efisiensi dapat diindikasikan oleh ketidakmampuan pemerintah desa melaksanakan pelayanan kepada masyarakat secara cepat, tepat, dan mudah baik dari segi waktu, biaya maupun prosedur pelayanan.Kelemahan kinerja pada aspek responsivitas dapat diindikasikan oleh ketidakmampuan pemerintah desa dalam menanggapi atau memenuhi harapan atau tuntutan masyarakat secara cepat dan tepat.Sedangkan kelemahan kinerja pada aspek kualitas layanan dapat diindikasikan oleh ketidakmampuan pemerintah desa dalam melaksanakan pelayanan yang memuaskan masyarakat mengenai prosedur pelayanan, persyaratan teknik dan administrasi pelayanan, tanggung jawab aparat pelayanan, dan waktu penyelesaian pelayanan (Dunn, 2015).

Selain itu, dalam rangka memaksimalkan kinerja pemerintah desa dengan menggunakan kemajuan tekhnologi dirasa masih belum mampu terwujud. Hal ini dikarenakan kesiapan infrastruktur belum dapat dipenuhi. Selain itu masyarakat yang belum melek terhadap internet pun menjadi kendala jika teknologi informasi akan diberlakukan. Penggunaan gadget masih didominasi anak anak dan remaja, sedangkan masyarakat yang bertindak sebagai pencari nafkah tidak begitu akrab dengan teknologi terutama smartphone. Sehingga penting dirasa untuk mempersiapkan infrastruktur dan pematangan SDM terlebih dahulu sebelum 
meluncurkan program pemerintah desa berbasis internet. Namun, jika kelengkapan infrastruktur dan sumber daya manusia sudah siap untuk menerima program berbasis internet tentu merupakan sebuah kemajuan yang sangat baik bagi masyarakat maupun bagi program yang dijalanakan karena akan meningkatkan efektifitas dan efisien dalam pelaksanaan program pemerintah.

\section{Kesimpulan}

1. Problem penyimpangan penggunaan smartphone pada anak masih belum disadari oleh orang tua dan pentingnya campur tangan pemerintah dalam menanggulangi penyalahgunaan gadget pada anak.

2. Partisipasi masyarakat dalam pembangunan masih belum maksimal sehingga perlu ditingkatkan melalui forum forum perencanaan pembangunan mulai tingkat RT/RW, Dusun sampai tingkat Desa. Pemerintah desa berperan sebagai pihak penerima aspirasi dan pengambil kebijakan sesuai dengan tingkatan kebutuhan dan keterdesakan pembangunan.

3. Penggunaan teknologi informasi dalam pelaksanaan program pemerintah belum dapat dilakukan di Desa Sidorejo, Kebonsari, Kabupaten Madiun belum dapat diwujudkan karena belum siapnya infrastruktur dan kemampuan sumber daya manusia untuk mengakses informasi dengan pemanfaatna informasi melalui internet.

\section{Saran}

Untuk mengatasi problem di atas maka solusi yang dapat dilakukan sebagai berikut:

1. Orang tua dapat membuat kesepakatan dengan anak-anak kapan mereka akan menggunakan gadgetnya. Misalnya seminggu dua kali, atau sekali pada hari libur saja. Termasuk durasinya, atur batasan durasi/lamanya waktu mereka mengakses gadget. Usahakan membangun kedisiplinan dari pengaturan waktu akses ini dengan membuat kesepakatan dengan anak. Usahakan anak-anak tidak mengakses gadget terlalu lama setiap harinya. Upayakan untuk meminimalisir melakukan komunikasi menggunakan alat-alat seperti bbm, line, WhatsApp dengan anak. Upayakan untuk mengoptimalkan komunikasi manual dengan 
anak, ajak anak berdiskusi, berdialog, tanya jawab untuk membangun kultur komunikasi yang baik di keluarga.

2. Guru sebaiknya memberi pengertian tentang pentingnya belajar dan melakukan kegiatan positif baik di dalam lingkungan sekolah maupun diluar. Sehingga para anak dapat melakukan kegiatan positif dan bersosialisasi dengan lingkungannya dan tidak menggunakan gadget secara berlebihan yang dapat mengurangi tingkat sosialisasi mereka.

3. Pemerintah dapat membuat undang-undang pemberlakuan pembatasan penggunaan perangkat elektronik ataupun gadget untuk anak usia di bawah 18 tahun. Pemerintah Desa dan PBD membuat Perdes tentang pembatasan penggunaan gadget bagi anak dan jam wajib belajar.

4. Perlunya mengadakan sosialisasi melalui PKK dan forum arisan RT kepada orang tua tentang bahaya gadget bagi anak dan solusinya.

5. Mengadakan kegiatan kegiatan positif seperti perlombaan, latihan, les, bimbingan belajar yang dimotori oleh Karang Taruna Desa secara berkala dan visioner.

6. Membuat leaflet/brosur/ banner tentang bahaya penggunaan gadget bagi anak seperti dampak kerusakan otak, radiasi, disosialisasi anak, ketergantungan kepada internet, penyimpangan perilaku seksual anak dan penyalahgunaan jejaring sosial.

7. Perlunya membuat Forum anak yang bertugas untuk melakukan fasilitasi dan pembinaan serta pengawasan kegiatan anak di luar sekolah, dalam rangka: (i) peningkatan kapasitas dan kepribadian anak melalui media yang edukatif, komunikatif, rehabilitatif, rekreatif maupun promotif, (ii) Pelibatan anak dalam proses pembuatan kebijakan pemerintah Desa setempat, kepengurusan forum anak terdiri dari aparatur pemerintah Desa, lembaga Desa, Unsur institusi pendidikan anak (formal dan non formal) serta pemerhati sosial pendidikan.

8. Perlu diadakan komunitas teman sebaya bagi anak untuk menjalin komunikasi sebagai sarana untuk berbagi permasalahan tentang anak dengan bimbingan fasilitator yang dibentuk oleh Pemerintah Desa.

9. Perlunya pemahaman orang tua terhadap bahaya gadget.

10. Pemerintah Desa melakukan kerjaasama dengan Dinas Komunikasi dan Informatika untuk membatasi konten Pornografi, kekerasan dan SARA pada jaringan internet dan mensosialisasikan fitur internet aman untuk anak.

11. Membuat film tentang bahaya gadget yang ditampilkan pada pertemuanpertemuan Desa.

12. Melakukan kerja sama dengan pihak sekolah yang ada di Desa untuk mensosialisaikan film pendek tentang bahaya gadget. 
13. Pemerintah Desa membuat dan menjalankan aplikasi sejenis website sebagai pusat informasi Desa secara massif.

14. Mempersiapkan infrastruktur dan melakukan pelatihan pemanfaatan teknologi informasi bagi masyarakat.

Untuk mengatasi problem di atas maka kami memberikan tawaran solusi sebagai berikut:

1. Mengingat bidang pelayanan masyarakat merupakan ujung tombak gambaran keberhasilan pemerintahan desa, maka kritik yang konstruktif dari masyarakat perlu mendapat respon yang cepat dari pengambil kebijakan di desa. Bentuk respon konkrit yang dapat dilakukan adalah dengan melakukan pendekatan umum maupun persuasif terhadap unsur aparat pelayan masyarakat meliputi kegiatan pelatihan manajemen pelayanan prima, komunikasi langsung, penerapan reward and punishman serta membuat regulasi alur pelayanan publik yang komprehensif dan mudah dipahami oleh masyarakat secara umum. Penyampaian informasi publik tidak hanya dilakukan dengan penyampaian langsung akan tetapi dapat dikembangkan melalui sistem informasi manajemen layanan publik berbasis internet (website desa) dan non internet seperti pembuatan brosur, pamphlet, spanduk dan surat pemberitahuan terbuka yang diletakkan pada ruang2 publik. Sosialisasi tersebut dilakukan sebagai bentuk transparansi, pertanggungjawaban kinerja pemerintah desa kepada masyarakat dan untuk menekan angka penyimpangan atau tindak pidana korupsi di desa termasuk mendukung upaya pemerintah guna menghapus praktik pungutan liar (pungli).

2. Aspirasi masyarakat di bidang pemberdayaan lingkungan yang belum direalisasikan dapat disampaikan melalui lembaga desa yang membidangi, BPD, perangkat desa, pengurus $\mathrm{RT} / \mathrm{RW}$ dan melalui musyawarah perencanaan pembangunan desa (musrenbangdes). Sehingga aspirasi masyarakat dapat tertampung dan bisa direalisasikan oleh pemerintah desa.

3. Pemerintah desa harus memperhatikan semua aspek pembangunan dan pemberdayan masyarakat, tidak hanya pembangunan infrastruktur akan tetapi juga terkait dengan pemberdayaan manusia/ non fisik/SDM dalam bentuk peningkatan kapasitas pengetahuan, perubahan sikap dan ketrampilan agar masyarakat dapat hidup mandiri dan tidak bergantung pada bantuan atau subsidi dari pemerintah, Misalnya: pemberian ketrampilan dibidang pemanfaatan teknologi informasi, mekanik mesin (perbengkelan), pertanian (pembuatan pupuk), dan peternakan (cara pemberian vaksin dan pakan yang efektif). 


\section{DAFTAR PUSTAKA}

Ahmadi, A. (2007). Psikologi Sosial. Jakarta: Rineka Cipta.

B, R. (2013). Kebijakan Publik: Membangun Mutu Pendidikan Menuju Era Global . Bandung: CV Smile's Indonesia Institute.

Creswell, J. W. (2014). Penelitian Kualitatif Dan Desain Riset. (S. Z. Qudsy, Ed., \& A. L. Lazuardi, Trans.) Yogyakarta: Pustaka Pelajar.

Dunn, W. (2015). Pengantar Analisis Kebijakan Publik . Yogyakarta: UGM Press.

Dwiyanto, \& dkk. (2010). Reformasi Birokrasi Publik di Indonesia. Pusat Studi Kependudukan dan Kebijkana. Yogyakarta: UGM.

edy, A. (2015). Ayah Edy Menjawab Problematika Orangtua ABG dan Remaja. Jakarta: Noura Book Publishing.

Irawan, J., \& Armayati, L. (2013). Pengaruh Kegunaan Gadget Terhadap Kemampuan Bersosialisasi Pada Remaja. An-Nafs, 29.

KBBI. (2016, April Tuesday). Kamus Besar Bahasa Indonesia, 1.9. Retrieved April Tuesday, 2017, from Kamus Versi Online/Daring: http://kbbi.web.id/gawai-2

Kominfo, p. (2017, Maret 29). Pemkot Madiun Siapkan Kota Madiun Sebagai Kota Layak Anak. Retrieved April 12, 2017, from Pemerintah Kota Madiun: http://madiunkota.go.id/?p=740

Kurniawan, A. (2015). Transformasi Pelayanan Publik. Yogyakarta: PT Pembaharuan.

Lukman, S. (2012). Manajemen Kualitas Pelayanan Publik . Jakarta: STIA-LAN Press.

Manumpil, B., Ismanto, Y., \& Onimbala, F. (2015). Hubungan Penggunaan Gadget Dengan Tingkat Prestasi Siswa Di SMA Negeri 9 Manado. ejornal Keperawatan, 1.

Marzali, A. (2014). Struktural-Fungsionalisme. Journal Universitas Indonesia, 127.

Nasrudin, A. (2014, September 22). Kementerian Agama BAlai Diklat Keagamaan Bandung. Retrieved April 11, 2017, from Implementasi E-Government Di Pemerintah Kabupaten

Bandung: 
http://bdkbandung.kemenag.go.id/jurnal/371-implementasi-e-government-dipemerintah-kabupaten-bandung

Nurudin. (2009). Pengantar Komunikasi Massa. Jakarta: PT. Rajawali Pers.

Pratiwi, Y., Wijaya, A. F., \& Prasetyo, W. Y. (2013). Implementasi E-Service Pada Organisasi Publik di Bidang Pelayanan Pendidikan Studi tentang Program Penerimaan Siswa Baru (PSB) Real Time Online DInas Pendidikan Kota Malang. Jurnal Administrasi Publik, 206.

S, P. (2016). Kepemimpinan Pemerintahan di Indonesia. Jakarta: Rineka Cipta.

Said, I. (2013). Paradigma Sosial Dan Masyarakat . JUrnal Berita Sosial, 35.

Sinambela, \& dkk. (2010). Reformasi Pelayanan Publik: Teori Kebijakan dan Implementasi. Jakarta: Bumi Aksara.

Sosiawan, E. A. (2008). Tantangan dan Hambatan dalam Implementasi EGovernment di Indonesia. Seminar Nasional Informatika UPN "Veteran" Yogyakarta (p. 99). Yogyakarta: UPN "Veteran" Yogyakarta.

Suharto, E. (2007). Pekerjaan Sosial dan Dunia Industri: Memperkuat Tanggungjawab Sosial Perusahaan. Bandung: Rafika Aditama.

Suharto, E. (2009). Membangun Masyarakat Memberdayakan Rakyat. Bandung: Rafika Aditama.

Wikipedia. (2016, Desember 4). Ensiklopedia Bebas. Retrieved April 11, 2017, from Gawai: https://id.wikipedia.org/wiki/Gawai

\section{Undang-undang}

UU Nomor 36 Tahun 1999 pasal 4 tentang Pembinaan Telekomunikasi

UU Nomor 11 Tahun 2008 Tentang Informasi Dan Transaksi Elektronik

UU Nomor 5 Tahun 1979 tentang Desa

UU Nomor 22 Tahun 1999 Tentang Pemerintahan Daerah

UU Nomor 32 Tahun 2004 tentang Pemerintahan Daerah

UU Nomor 6 Tahun 2014 Tentang Desa

UU Nomor 25 Tahun 2009 Tentang Pelayanan Publik 